\title{
Diagnostic Techniques of the Rod-shaped Nuclear Virus Infection in the Kuruma Shrimp, Penaeus japonicus
}

\author{
Kazuo Momoyama*1, Midori Hiraoka*1, Kiyoshi Inouye*2, \\ Takeshi Kimura*3 and Heiji Nakano*3 \\ ${ }^{* 1}$ Yamaguchi Prefectural Naikai Fisheries Experiment Station, Yamaguchi 754, Japan \\ *2 National Research Institute of Aquaculture, Inland Station, \\ Tamaki, Mie 519-04, Japan \\ ${ }^{*}$ Kumamoto Prefectural Fisheries Research Center, Senouchi, \\ Ohyano-cho, Amakusa-gun, Kumamoto 869-36, Japan
}

(Received July 20, 1995)

\begin{abstract}
Rapid and confirmative diagnostic methods for the rod-shaped nuclear virus (RV-PJ) infection in the kuruma shrimp (Penaeus japonicus) by dark-field microscopy and transmission electron microscopy, respectively, were proposed.

Under a dark-field microscope virus particles were seen as numerous fine particles (about $0.5 \mu \mathrm{m}$ ) in the hemolymph. In stomach cuticular epidermis, virus-infected nuclei were seen as sharply outlined homogenous white bodies, $10-15 \mu \mathrm{m}$ in diameter, round or oblong in shape and hemocytic encapsulations of necrotic cells as small brown masses (about 20-50 $\mu \mathrm{m}$ ). Under a transmission electron microscope virus particles were seen as virions $(400 \times 150 \mathrm{~nm})$ or capsids $(390 \times 85 \mathrm{~nm})$ in negatively stained preparations from hemolymph and stomach.
\end{abstract}

Key words : diagnostic techniques, RV-PJ, virus, kuruma shrimp, Penaeus japonicus

Since 1993 a very severe epizootic has been attacking the cultured kuruma shrimp, Penaeus japonicus, at farms in Japan, causing high mortalities of more than $80 \%$. In 1993 such heavy losses were observed only at the farms where juvenile $P$. japonicus had been introduced from China and at their neighboring farms (Nakano et al., 1994), whereas in 1994 the same epizootic was widely spread in other areas, although no seed $P$. japonicus were introduced from any foreign nations.

Histopathological study of moribund shrimp demonstrated that it is a new disease in penaeid shrimp, and homogeneous hypertrophy of nuclei in the infected cells in various tissues or organs originated from meso- and ectoderm, such as stomach cuticular epidermis (most heavily infected), hematopoietic tissue and lymphoid organ, are the most characteristic cytopathological change in this disease (Momoyama et al., 1993). Electron microscopy revealed rod-shaped, enveloped, nonoccluded virus in such hypertrophied nucleus, and the virus was temporarily named RV-PJ (rod-shaped nuclear virus of $P$. japonicus) (Inouye et al., 1994) or bacilliform virus
(Takahashi et al., 1994).

It is well known that in some viral diseases of insects virus particles are released in the hemolymph from the lesions (Fukuhara, 1979). In the course of the subsequent histopathological study on RV-PJ infection in $P$. japonicus, we also found numerous virus particles in the hemolymph from the moribund shrimp, causing viremia.

In the present study we aimed to establish the diagnostic method of RV-PJ infection based on the above mentioned histological changes as well as evidence of viremia. The present paper describes rapid and confirmative diagnostic methods, using darkfield and electron microscopy, respectively.

\section{Materials and Methods}

\section{Infected animals}

Infected $P$. japonicus used in this study were collected at some shrimp farms in Yamaguchi prefecture when the epizootic occurred, or were obtained by intramascular injection of filtered homogenate of the infected shrimp. 


\section{Dark-field microscopy}

Dark-field microscope used in this study was equipped with a wet-type condenser.

Detection of virus particles: One drop of hemolymph drawn from the heart of shrimp into a syringe was placed on a clean slide glass. After applying cover slip on the hemolymph, the preparation was observed under dark-field microscope.

Detection of virus-infected hypertrophied nuclei: The stomach was dissected and fixed in 10\% formalin solution (Formalin fixation was not necessarily needed, but it made subsequent procedures easier). The cuticular epidermis was peeled off the stomach with a tapering forceps, and then spread out in a small amount of $10 \%$ formalin solution on a slide glass. Excess solution was absorbed with filter paper at the edge of cover slip to make thin preparation.
The preparation was observed at the area where shrimp pigment cells were poorly distributed under dark-field microscope.

Stomachs of some specimens were cut into 2 pieces. One piece was used for observation of darkfield microscopy and the other piece for the conventional histology, and detection efficiencies of virusinfected nuclei by both methods were compared.

Possibility of detection by dark-field microscopy of virus-infected nuclei in the stomach cuticular epidermis of the affected shrimp preserved at $5^{\circ} \mathrm{C}$ or $-20^{\circ} \mathrm{C}$ was also tested. Infected animals used for this purpose were sacrificed in an iced sea water just before preservation.

\section{Electron microscopy}

When the shrimp was large enough for hemo-

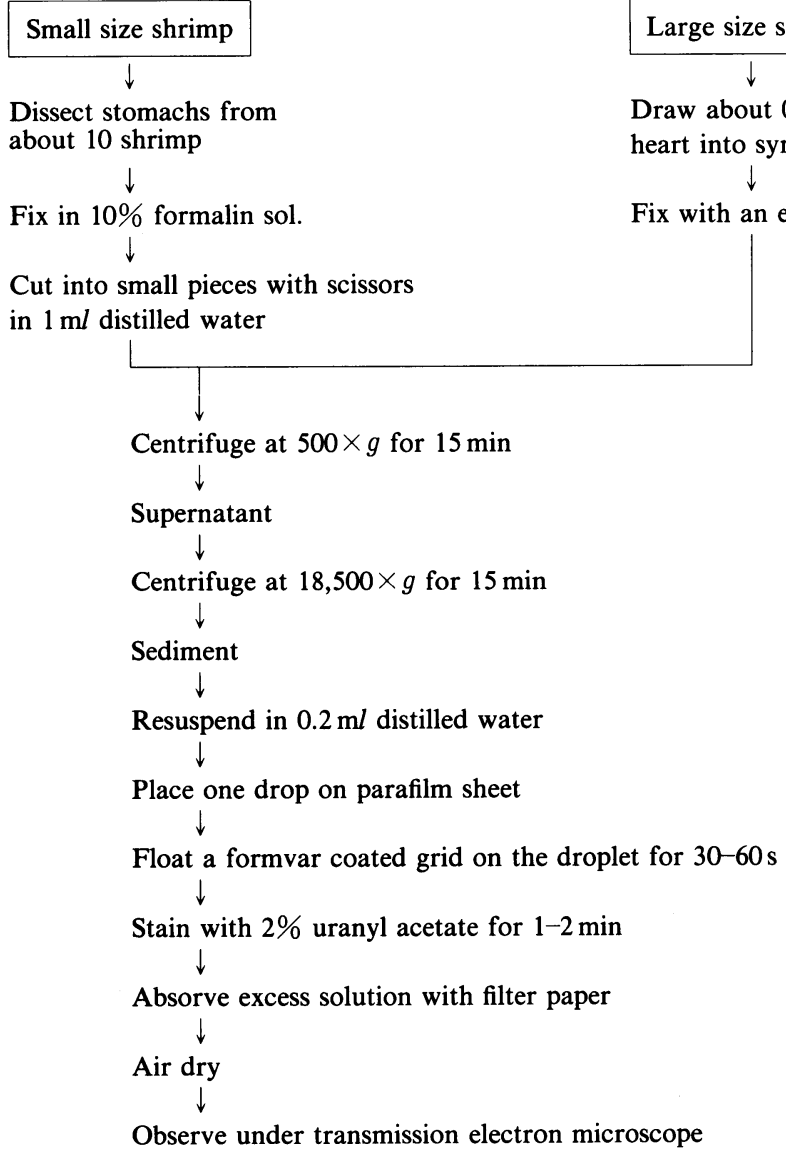

Fig. 1. Procedures used to make negatively stained preparation from the hemolymph and stomach for transmission electron microscopy. 
lymph to be drawn from the heart with syringe, the hemolymph was used for the preparation to detect virus particles, but when the animal was smaller, the stomach was used for it. These materials, after being fixed in $10 \%$ formalin solution and cleared by centrifugation at $500 \times g$ for $15 \mathrm{~min}$, were negatively stained with $2 \%$ uranyl acetate and observed under transmission electron microscope (Fig. 1).

\section{Results}

\section{Dark-field microscopy}

Virus particles: Numerous fine granule-like particles, nearly the same in size (abotu $0.5 \mu \mathrm{m}$ ) and taking Brown's movement (Fig. 2), were seen in the hemolymph from moribund shrimp. As described later, these particles were demonstrated to be RV-PJ particles by electron microscopy. Intensive decrease of hemocytes and coagulability of hemolymph were also noticed in these preparations.

Careful observation frequently detected very few fine particles even in normal hemolymph. However, these particles were very small in number and varied in size, and hence they were not considered as virus particles.

Virus-infected hypertrophied nuclei: Sharply out-

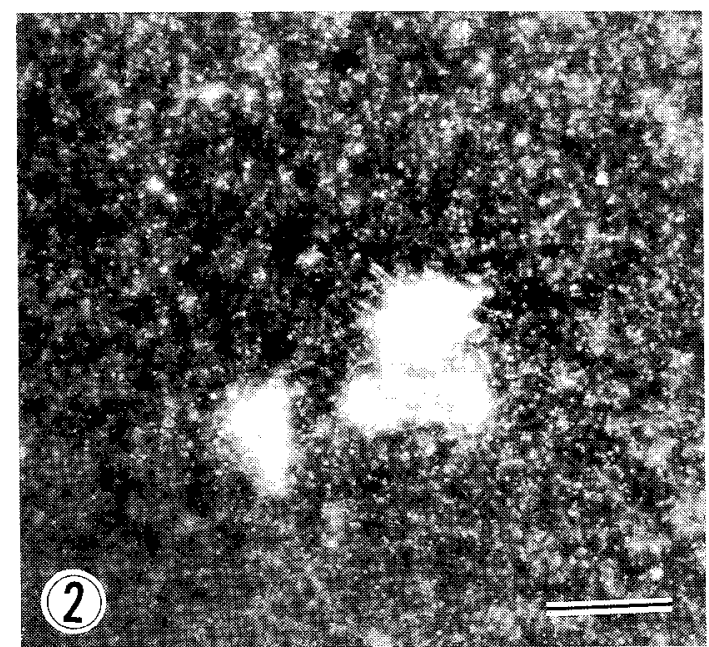

Fig. 2. Numerous virus particles in the hemolymph from the moribund shrimp observed under darkfield microscope. Since free virus particles are taking Brown's movement, this picture focused the stationary particles in contact with the cover slip. Three hemocytes are also seen in the center of the picture. Bar scale $=20 \mu \mathrm{m}$. lined white bodies, about $10-15 \mu \mathrm{m}$ in diameter, round or oblong in shape and showing almost homogeneous structure (Fig. 3) were seen in the cuticular epidermis of most preparations of affected stomach, but were never found in preparations from healthy shrimp (Fig. 4). These white bodies sometimes formed cherry blossom-like patterns (Fig. 5). In the preparations in which few white bodies were seen small brown masses, about $20-50 \mu \mathrm{m}$ in diameter (Fig. 6), were frequently observed.

Comparison of dark-field microscopy and conventional histology using paired pieces of the same stomach indicated that the white bodies and brown masses seen under dark-field microscopy corresponded to virus-infected hypertrophied nuclei (Fig. 7) and hemocytic encapsulations of necrotic cells (Fig. 8) in the conventional histology, respectively, since their morphology, distribution and abundance showed close resemblance between the two methods. Detection of virus-infected nuclei by the two methods generally showed good corresponding, except in the case of slight infection (Table 1). In most cases when slight infection was found in the conventional histology, neither virus particles in the hemolymph nor virus-infected nuclei in the stomach cuticular epidermis could be detected by darkfield microscopy. Moreover, dark-field microscopy especially for the stomach sometimes failed to detect the infection even when a heavy infection was found in conventional histology.

Detection of virus-infected nuclei in the affected stomach by dark-field microscopy was possible for the specimens preserved at $5^{\circ} \mathrm{C}$ within $6 \mathrm{~h}$, but was unable either for the specimens preserved at $5^{\circ} \mathrm{C}$ for $24 \mathrm{~h}$ or for frozen specimens.

\section{Electron microscopy}

Virus particles were easily detected mainly as free virions or mass of several virions in preparations from hemolymph, and as virions or capsids adhering to tissue fragments in preparations from stomach (Fig. 9). The mean length and diameter of virions were $400 \mathrm{~nm}$ and $150 \mathrm{~nm}$ respectively, and those of capsids were $390 \mathrm{~nm}$ and $85 \mathrm{~nm}$ respectively.

\section{Discussion}

Generally, dark-field microscopy is greatly useful to observe fine particles in fresh preparations. In the present study the method detected numerous RV-PJ 

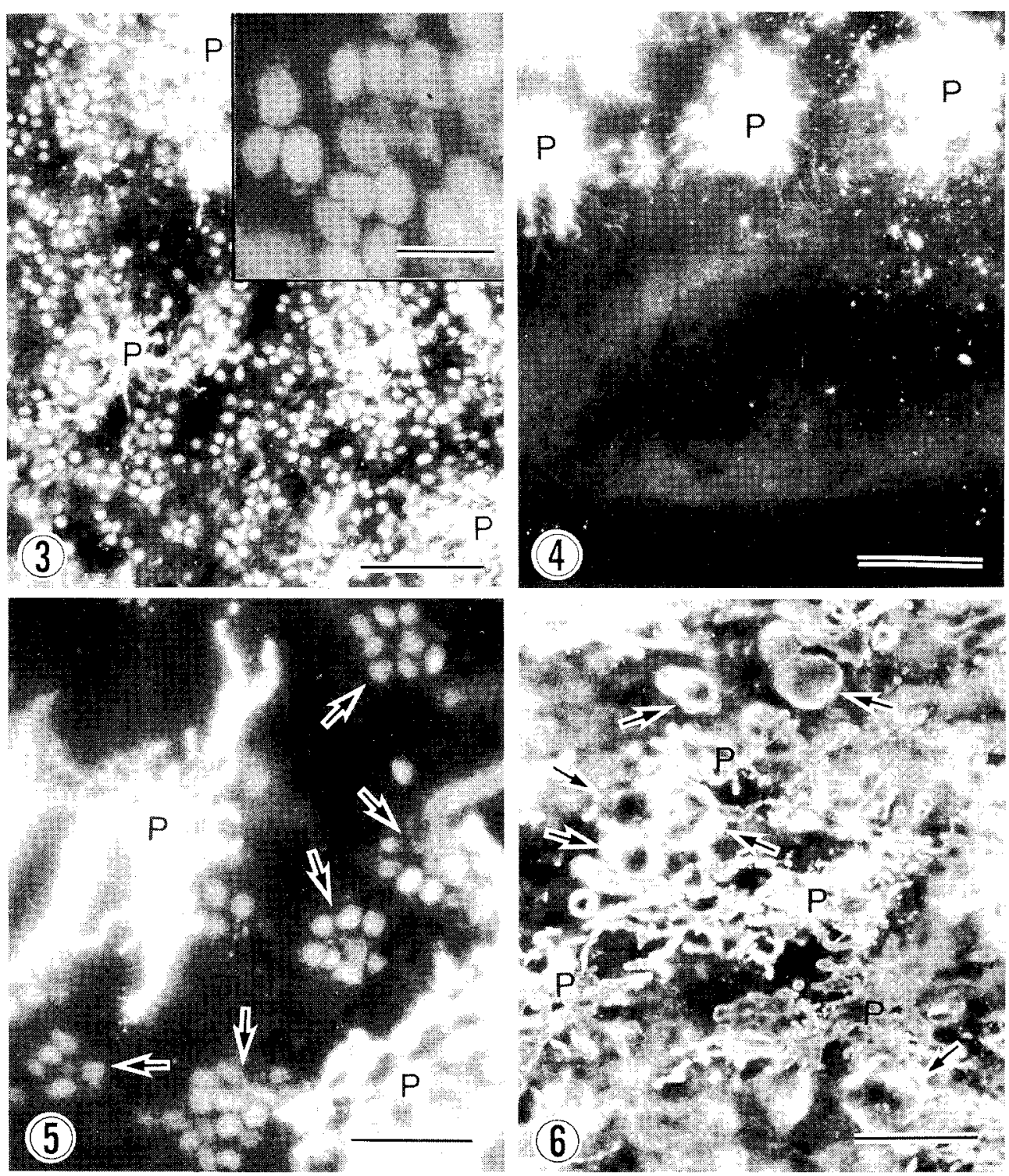

Fig. 3. Stomach cuticular epidermis of a moribund shrimp observed under dark-field microscope. Many virusinfected nuclei are clearly seen as white bodies at the area without shrimp pigments (P). Bar scale $=$ $100 \mu \mathrm{m}$. Inset: High-magnified virus-infected nuclei. Note sharply out-lined and almost homogeneous structure. Bar scale $=20 \mu \mathrm{m}$.

Fig. 4. Stomach cuticular epidermis of a healthy shrimp observed under dark-field microscope. No white bodies as shown in Fig. 3. are seen. P: Shrimp pigments. Bar scale $=100 \mu \mathrm{m}$.

Fig. 5. Cherry blossom-like patterns (arrows) of virus-infected nuclei in the stomach cuticular epidermis of an infected shrimp observed under dark-field microscope. P: Shrimp pigments. Bar scale $=50 \mu \mathrm{m}$.

Fig. 6. Brown masses (arrows) in the stomach cuticular epidermis of an infected shrimp observed under darkfield microscope. P: Shrimp pigments. Bar scale $=50 \mu \mathrm{m}$. 


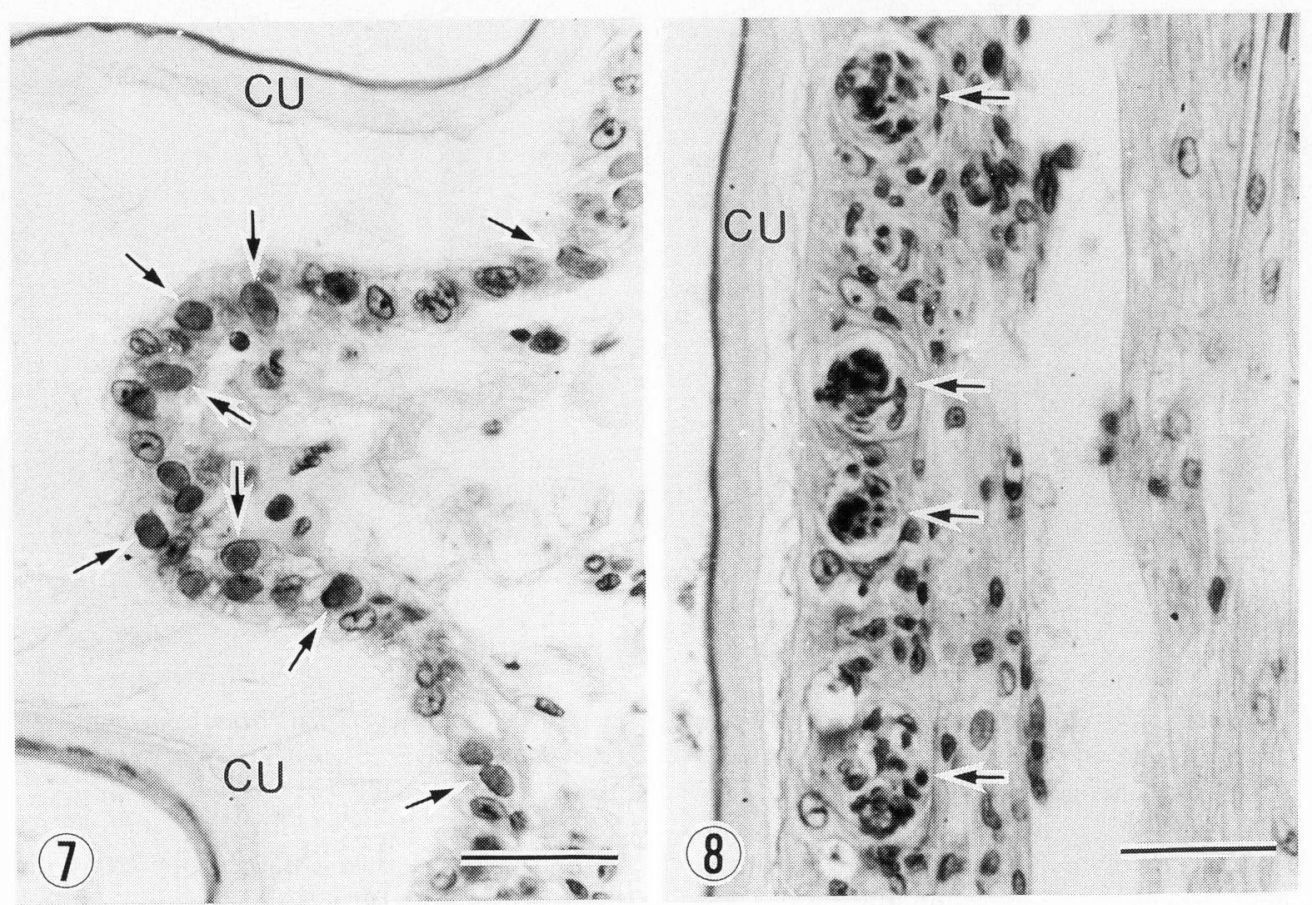

Fig. 7. Virus-infected hypertrophied nuclei (arrows) of a heavily affected stomach in the conventional histology. Note the nuclei are stained homogeneously with hematoxylin. CU: Cuticle. HE stain. Bar scale $=20 \mu \mathrm{m}$.

Fig. 8. Hemocytic encapsulations (arrows) of necrotic cells of an affected stomach in the conventional histology. Bacterial colonies, which are always seen in the center of the nodules in vibriosis, are not observed. CU: Cuticle. HE stain. Bar scale $=20 \mu \mathrm{m}$.

Table 1. Detections of virus particles and virus-infected hypertrophied nuclei in spontaneusly and experimentally infected shrimp by dark-field microscopy and conventional histology

\begin{tabular}{|c|c|c|c|c|c|c|c|c|c|}
\hline \multicolumn{5}{|c|}{ Spontaneously infected shrimp } & \multicolumn{5}{|c|}{ Experimentally infected shrimp } \\
\hline \multirow{2}{*}{ Farm } & \multirow{2}{*}{ No. } & \multirow{2}{*}{$\begin{array}{c}\begin{array}{c}\text { Conventional } \\
\text { histology }\end{array} \\
\begin{array}{c}\text { Infected } \\
\text { nuclei*2 }\end{array}\end{array}$} & \multicolumn{2}{|c|}{ Dark-field microscopy } & \multirow{2}{*}{$\begin{array}{l}\text { Inocu- } \\
\text { lation }\end{array}$} & \multirow{2}{*}{ No. } & \multirow{2}{*}{$\begin{array}{c}\begin{array}{c}\text { Conventional } \\
\text { histology }\end{array} \\
\begin{array}{c}\text { Infected } \\
\text { nuclei }\end{array}\end{array}$} & \multicolumn{2}{|c|}{ Dark-field microscopy } \\
\hline & & & $\begin{array}{c}\text { Virus } \\
\text { particles*1 }\end{array}$ & $\begin{array}{l}\text { Infected } \\
\text { nuclei*2 }^{* 2}\end{array}$ & & & & $\begin{array}{c}\text { Virus } \\
\text { particles }\end{array}$ & $\begin{array}{c}\text { Infected } \\
\text { nuclei }\end{array}$ \\
\hline \multirow{5}{*}{ A } & 1 & + & + & - & No & 1 & - & - & - \\
\hline & 2 & + & + & + & & 2 & - & - & - \\
\hline & 3 & ++ & + & - & & 3 & - & - & - \\
\hline & 4 & ++ & + & ++ & Yes & 1 & + & - & - \\
\hline & 5 & ++ & + & ++ & & 2 & + & - & - \\
\hline \multirow[t]{3}{*}{ B } & 1 & ++ & + & ++ & & 3 & ++ & - & - \\
\hline & 2 & ++ & + & ++ & & 4 & ++ & + & - \\
\hline & 3 & ++ & + & ++ & & 5 & ++ & ++ & + \\
\hline \multirow[t]{3}{*}{$\mathrm{C}$} & 4 & ++ & + & ++ & & 6 & ++ & + & ++ \\
\hline & 1 & + & - & - & & & & & \\
\hline & 2 & ++ & ++ & ++ & & & & & \\
\hline
\end{tabular}

-: Not detected, + : Few detected, ++ : Many detected.

${ }^{* 1}$ In the hemolymph, ${ }^{* 2}$ In the stomach cuticular epidermis. 

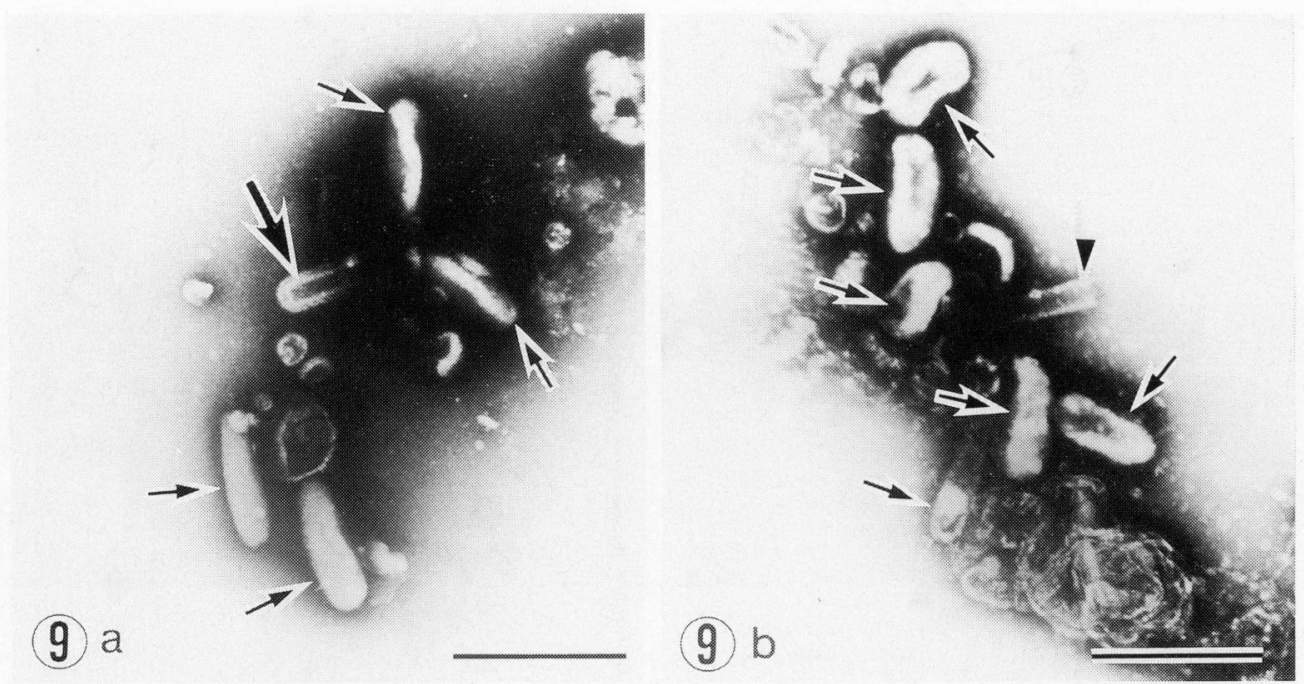

Fig. 9. Electron photomicrographs of negatively stained virus particles in preparations from hemolymph (9a) and stomach (9b). A large arrow indicates the penetration of dyes in the virion. Arrows indicate virions and the arrow head indicates a capsid. Bar scale $=400 \mathrm{~nm}$.

particles in the hemolymph from moribund shrimp. This finding provides an important information to the question which tissues of shrimp should be used for successful isolation and purification of the virus.

Dark-field microscopic diagnosis has already been developed and routinely practiced for baculoviral mid-gut gland necrosis (BNM) in larval $P$. japonicus (Momoyama, 1983). Cytopathological changes in RV-PJ infection and BMN are basically the same, i.e.; the virus replicates in the nucleus, produces no occlusion bodies and causes hypertrophy and homogeneous structure of the nucleus. The reason why the virus-infected nuclei are clearly seen in white is thought to result from increased reflected and diffracted rays due to the numerous virus particles in the nuclei.

Dark-field microscopy could not diagnose slight infections, and sometimes failed to detect virusinfected nuclei even in heavy infections probably because of disturbance by widely distributed pigment cells of shrimp. However, as dark-field microscopy has much advantages of rapidity, simplicity and low cost, the method can be easily applied for routine diagnosis at examination facilities. If examination facilities are not located near farms, moribund shrimp can be preserved in cool box for several hours or the hemolymph and stomach should be fixed in $10 \%$ formalin solution while/before transportation to the facilities.
Transmission electron microscopy easily detected RV-PJ virions or capsids in negatively stained preparations from hemolymph and stomach. The method confirms the reliability of dark-field microscopic diagnosis which is usually practiced before electron microscopy. Sizes of virions and capsids measured in negatively stained preparations in the prsent method were larger than those (Virion: $130 \pm$ $9 \mathrm{~nm}$ in diameter, nucleocapsid: $226 \pm 29 \times 84 \pm 6$ $\mathrm{nm})$ measured in ultra-thin sectioned preparations reported in the previous paper (Inouye et al., 1994). Negative stain method in the present study seems to indicate closer values to the true sizes of RV-PJ, since the process of the preparation in the present method includes less steps that may produce artifacts, compared to those for the conventional ultrathin section.

BMN is the other severe viral epizootic in $P$. japonicus of which susceptible life stages to the virus are limited in larval and early post-larval stages (Momoyama and Sano, 1989). The target organs of $\mathrm{BMN}$ virus are the mid-gut gland and the intestine (Momoyama, 1992), quite differing from those of RV-PJ. Since it is easy to excise stomach from shrimp without contamination with mid-gut gland tissue fragments, dark-field microscopy would precisely distinguish RV-PJ infection from BMN virus infection.

Recently systemic ectodermal and mesodermal 
baculovirus (SEMBV) infection in P. monodon was reported from Thailand (Wongteerasupaya et al., 1995). Target organs and histopathology of SEMBV are very similar to those of RV-PJ in P. japonicus. If a penaeid shrimp species is susceptible to both these two viruses, it may be impossible to distinguish RV-PJ infection from SEMBV infection by darkfield microscopic diagnosis developed in the present study. However, it is expected that the two viruses can be distinguished by electron microscopy using the negatively stained preparations, since SEMBV but not RV-PJ has the protrusion at the end of the virion. Since dark-field microscopy is rather low in sensitivity in diagnosis and most fisheries examination facilities are not equipped with transmission electron microscope due to the expensiveness, serological or molecular biological techniques should be developed to increase the efficiency of the diagnosis of these viral diseases.

\section{Acknowledgments}

We would like to express our sincere thanks to Dr. Y. Inui, National Research Institute of Aquaculture, for critically reviewing the manuscript.

\section{References}

Fukuhara, T. (1979): Insect Pathology. Gakkaishuppan Center, Tokyo, 218 pp. (In Japanese).

Inouye, K., S. Miwa, N. Oseko, H. Nakano, T. Kimura, K. Momoyama and M. Hiraoka (1994): Mass mortalities of cultured kuruma shrimp, Penaeus japonicus, in Japan in
1993: Electron microscopic evidence of the causative virus. Fish Pathol., 29, 149-158.

Momoyama, K. (1983): Studies on baculoviral mid-gut gland necrosis of kuruma shrimp (Penaeus japonicus)III. Presumptive diagnostic techniques. Fish Pathol., 17, 263-268.

Momoyama, K. (1992): Viral diseases of cultured penaeid shrimp in Japan. In "Proceedings of the diseases of cultured penaeid shrimp in Asia and the United States" (ed. by W. Fulks and K. L. Main). The Oceanic Institute, 185-192.

Momoyama, K., M. Hiraoka, H. Nakano, H. Koube, K. Inouye and N. Oseko (1994): Mass mortalities of cultured kuruma shrimp, Penaeus japonicus, in Japan in 1993: Histopathological study. Fish Pathol., 29, 141-148.

Momoyama, K. and T. Sano (1989): Developmental stages of kuruma shrimp, Penaeus japonicus Bate, susceptible to baculoviral mid-gut gland necrosis (BMN) virus. J. Fish Diseases, 12, 585-589.

Nakano, H., H. Koube, S. Umezawa, K. Momoyama, M. Hiraoka, K. Inouye and N. Oseko (1994): Mass mortalities of cultured kuruma shrimp, Penaeus japonicus, in Japan in 1993: Epizootiological survey and infection trials. Fish pathol., 29, 135-139.

Takahashi, Y., T. Itami, M. Kondo, M. Maeda, R. Fujii, S. Tomonaga, K. Supamattaya and S. Boonyaratpalin (1994): Electron microscopic evidence of bacilliform virus infection in kuruma shrimp (Penaeus japonicus). Fish Pathol., 29, 121-125.

Wongteerasupaya, C., J. E. Vickers, S. Sriurairatana, G. L. Nash, A. Akarajamorn, V. Boonsaeng, S. Panyim, A. Tassanakajon, B. Withyachumnarnkul and T. W. Flegel (1995): A non-occluded, systemic baculovirus that occurs in cells of ectodermal and mesodermal origin and causes high mortality in the black tiger prawn Penaeus monodon. Dis. Aquat. Org., 21, 69-77. 